Review

\title{
Scoping Review on Interventions for Physical Activity and Physical Literacy Components in Brazilian School-Aged Children and Adolescents
}

\author{
Valter Cordeiro Barbosa Filho ${ }^{1,2, *} \mathbb{D}^{\mathbb{D}}$, Wallingson Michael Gonçalves Pereira ${ }^{1} \mathbb{C}$, Bianca de Oliveira Farias ${ }^{1}$, \\ Thereza Maria Magalhães Moreira ${ }^{1}{ }^{(D}$, Paulo Henrique Guerra ${ }^{3}{ }^{\circledR}$, Ana Carolina Melo Queiroz ${ }^{1}$, \\ Victor Hugo Santos de Castro ${ }^{1}$ and Kelly Samara Silva ${ }^{4}$ (i)
}

1 Post-Graduate Program in Collective Health, Ceara State University, Fortaleza 60714-903, Brazil; wallingsonmichaelgp@hotmail.com (W.M.G.P.); biancafariasnutri@gmail.com (B.d.O.F.); tmmmoreira@gmail.com (T.M.M.M.); acmq28@hotmail.com (A.C.M.Q.); vsantosdecastro@gmail.com (V.H.S.d.C.)

2 Federal Institute of Education, Science and Technology of Ceara, Aracati 62930-000, Brazil

3 Federal University of Fronteira Sul, Chapeco 89802-112, Brazil; paulo.guerra@uffs.edu.br

4 Research Center for Physical Activity and Health, Federal University of Santa Catarina, Florianopolis 88040-900, Brazil; ksilvajp@gmail.com

* Correspondence: valtercbf@gmail.com

check for updates

Citation: Filho, V.C.B.; Pereira, W.M.G.; Farias, B.d.O.; Moreira T.M.M.; Guerra, P.H.; Queiroz, A.C.M.; Castro, V.H.S.d.; Silva, K.S. Scoping Review on Interventions for Physical Activity and Physical Literacy Components in Brazilian School-Aged Children and Adolescents. Int. J. Environ. Res. Public Health 2021, 18, 8349. https://doi.org/10.3390/ijerph18168349

Academic Editors: João Martins and João Costa

Received: 11 June 2021

Accepted: 1 August 2021

Published: 6 August 2021

Publisher's Note: MDPI stays neutral with regard to jurisdictional claims in published maps and institutional affiliations.

Copyright: () 2021 by the authors. Licensee MDPI, Basel, Switzerland. This article is an open access article distributed under the terms and conditions of the Creative Commons Attribution (CC BY) license (https:// creativecommons.org/licenses/by/ $4.0 /)$.

\begin{abstract}
This scoping review mapped the existing evidence on interventions to promote physical activity (PA) and/or components of physical literacy (PL) in Brazilian school-aged children and adolescents. Nine electronic databases and gray literature were consulted in May 2020, with no limit on year or language. School-based intervention studies (6 to 18 years old, primarily) that assessed PA or PL components (PA-related factors or attributes) were eligible. The studies were stratified by children ( $<12$ years of age) and adolescents ( $\geq 12$ years of age). A total of 63 documents were included, which refer to 42 different intervention studies. Twenty-five interventions focused on adolescents and 17 on children. The most-used strategies in the interventions were changes in physical and environmental education classes, extracurricular PA sessions, and health education. No study has analyzed all components of PL or evaluated PL using specific protocols or instruments. PA attributes were the most studied components (30 studies). This review identified the need to conduct interventions with strategies that target all components of PL, representing important elements for a research agenda that underlies school interventions that contribute to an active lifestyle.
\end{abstract}

Keywords: physical literacy; physical activity; intervention; children; adolescents

\section{Introduction}

The World Health Organization's Global Action Plan on Physical Activity (PA) aims to increase PA and reduce sedentary behavior by guiding the creation of active societies, environments, people, and systems by 2030 [1]. Therefore, actions are proposed to transform social norms and attitudes that include enjoyable, affordable, socially, and culturally appropriate experiences of PA, which provide mass participation, behavior change, health, and physical literacy (PL). In addition, the document highlighted that a school-based environment reinforces lifelong health and PL according to individual, social, cultural, and economic features. This universal document invites the world to perceive PL as an important component of individual and collective actions to promote PA and health in the global population.

PL refers to a set of characteristics or attributes that expand an individual's potential to become involved and maintain the practice of PA [2]. Thus, PL components involve not only the PA behavior (e.g., active commuting to school, regular PA practice in sports, and others) but also PA-related factors (e.g., motivation, self-efficacy, social support, and 
environmental factors) and attributes (e.g., physical fitness and motor behavior) [3-5] that incorporate experiences and enrich an active lifestyle. Although there is no direct empirical test of the effect of PL on health, evidence supports that some of the core components of PL, particularly motor competence, motivation, and affect, may influence PA behavior and, by extension, health outcomes [6].

Consequently, interventions aimed at promoting PA should assess beyond the behavior to recognize the benefits of these interventions in different aspects that involve movements (attributes and associated factors of PA). Some countries, such as Canada, the United Kingdom, and Australia, have advanced in studies on the evaluation and promotion strategies of PL in children and adolescents [2,7]. In particular, a systematic review was published in 2012 [8] and synthesized data from 129 intervention studies that examined PL's effects on PA factors, behavior, and attributes. However, no intervention with children and adolescents from low- and middle-income countries has been reported [8]. Lowand middle-income countries have high rates of physical inactivity among children and adolescents, and they are at high risk for social and environmental elements (e.g., violence and unstructured schools) that may negatively impact PA and PL components [9]. Thus, improving PA, PL, and health in this context is part of the global health agenda [1].

In Brazil, a middle-income country, some reviews have summarized important evidence on the promising results of interventions to promote PA in children and adolescents [10-12]. However, these reviews have only presented information about PA behavior but have not considered the breadth and relevance of the different components of PL (such as motor behavior, physical fitness, and social and psychological aspects of PA). The different components of PL contribute systematically to the adoption and maintenance of an active lifestyle in children and adolescents and on the health of this population [6]. Therefore, a review that summarizes the methodological aspects, intervention strategies, and main results on this theme can guide future studies and practices on interventions to promote the PA, PL, and comprehensive health of school-aged children and adolescents.

Thus, the present scoping review aimed to map intervention studies to promote PA or other PL components among Brazilian school-aged children and adolescents. Our review is based on the following question: What is the existing evidence on interventions aimed at promoting PA or other PL components-PA factors and attributes-in Brazilian school-aged children and adolescents?

\section{Materials and Methods}

\subsection{Protocol}

This scoping review followed the recommendations of the Joanna Briggs Institute manual [13] and was reported in accordance with the guidelines recommended by the Preferred Reporting Items for Systematic Review and Meta-Analyses Extension for Scoping Reviews (PRISMA-ScR) [14], as detailed in Table S1. However, this study was not registered.

\subsection{Eligibility Criteria}

Considering the review question, the eligibility criteria were based on the population concept-context domains.

(I) Concept: Studies were included if they performed any intervention strategy that aimed at promoting PA or any components of PL. The components of PL were operationalized in modifiable PA-related factors (e.g., motivation, self-efficacy, interpersonal support, and environmental factors), PA behavior (e.g., weekly volume of PA), and attributes (e.g., physical fitness and motor behavior) [3,6]. PA was considered based on the WHO global action plan to promote PA [1], which is understood as any movement performed of a musculoskeletal nature that has energy expenditure as a result, and PA measurements were included regardless of the type or domain of PA (leisure, work, and active commuting) or type of measurement (subjective and objective). Modifiable PA factors were considered based on the following dimensions proposed by Keegan et al. [15]: cognitive, social, psychological, and physical dimensions. They were included independently on the scales and 
instruments used to estimate modifiable PA factors. PA attributes include cardiorespiratory and musculoskeletal fitness, flexibility, balance, coordination, and body composition (e.g., body mass index (BMI)) as its components [5,6], and these variables can be measured using direct or field tests.

(II) Population and Context: Studies were included if they evaluated children and adolescents (aged 6 to 18 years) enrolled in Brazilian schools. Studies that exclusively considered specific populations (e.g., children with musculoskeletal, neurofunctional, or metabolic diseases) were not included.

No restrictions were considered for experimental designs (all experimental studies), including studies without randomization between groups and no control groups. No limits were imposed on the publication year or language of the articles.

\subsection{Sources of Evidence}

The search was performed in May 2020 and updated in June 2021 (Table S2) in the following electronic databases: ERIC, Embase, MEDLINE/PubMed, LILACS, PsycINFO, SciELO, Scopus, SPORTDiscus, and Web of Science. Complementary searches were performed in the Brazilian Digital Library of Theses and Dissertations (BDTD), Google Scholar, specialized websites (Brazilian Society on Physical Activity and Health or SBAFS and Projeto Esporte Brasil or PROESP-BR), and was supplemented by a manual search of references in the reference lists of articles, aiming at finding relevant studies that were not included in the electronic databases (including gray literature).

\subsection{Search Strategies}

The search strategies included terms obtained from the existing literature in the area and were refined through consultations with specialists in the field. The search was structured in both Medical Subject Headings (MeSH) and text words presented in the literature. The terms were combined using truncation symbols and Boolean operators ("OR", "AND", and "NOT"). The search equations are presented in Tables S3 and S4.

\subsection{Study Selection}

The studies were incorporated into a library in EndNote Web after the search, and duplicates were eliminated before the selection process. At least two reviewers (W.M.G.P., V.H.S.d.C. and/or B.d.O.F.) independently performed the selection process, and the discrepancies between the reviewers were resolved by a third reviewer (V.C.B.F.). The study selection was performed in two stages: (1) screening of titles and abstracts and (2) reading of the full text. Only studies that met all eligibility criteria were included in the final report. All studies excluded at this stage were duly justified in the flow chart below according to the recommendations of PRISMA-ScR [14].

\subsection{Data Extraction}

One of the three reviewers conducted this phase (W.M.G.P., B.d.O.F. and A.C.M.Q.) using a standardized data extraction spreadsheet and the extracted data were revised by another reviewer. The extracted information included the characteristics of the studies (reference, year, place and type of study, and region in Brazil), population (sample size, school year, number of schools, age group, and eligibility criteria), interventions (type of intervention, time, and intervention strategies), and outcomes (measurement and results on PA factors, PA behavior, and/or PA attributes). Considering that this was a scoping review and aimed to map research independently of its quality, the risk of bias was not assessed [13].

\subsection{Data Synthesis}

A descriptive synthesis of the studies was adopted to describe the characteristics of the publications retrieved in this review (population, context, and concept). The components of PL that were evaluated in the included studies were presented in three domains: PA- 
related factors (psychological, social-environmental, and cognitive, such as self-esteem, satisfaction, self-efficacy, attitude, knowledge, and social support for PA), PA behaviors (level, time, and practice of PA), and attributes (motor behavior, locomotor ability, physical fitness, endurance, flexibility, and anthropometry) $[3,6]$.

Children (up to 12 years old) and adolescents (12 to 18 years old) represent two populations with particular characteristics $[2,11,16]$; thus, we synthesized the data according to age groups. The relevance of mapping different types of intervention strategies is based on age groups [13]. The strategies were organized in physical education classes; other strategies focused on changing the school environment, used electronic media, extracurricular PA sessions, and extracurricular sessions of health education, and focused on family and/or community [17]. Similarly, studies were organized by the outcome groups of PL dimensions, aiming at summarizing studies that evaluated and reported the effect of the intervention for each PA and PL outcome.

\section{Results}

After the electronic search, we found 3713 potential titles and abstracts (2944 studies after exclusion of duplicates). At the end of the first evaluation stage, 97 studies were considered eligible, and full-text reading was performed. Forty-three of these studies were not considered eligible, mainly because they did not measure the outcomes of interest (14 studies) or were not intervention studies (11 studies). Nine references were added after reading the reference lists of the retrieved documents or website searches. Thus, 63 documents (54 articles and nine theses and dissertations) met the eligibility criteria, representing 42 different studies that were summarized in this review [18-80] (Figure 1).

Overall, 17 and 25 intervention studies were performed in children and adolescents, respectively. In the study design, most studies were randomized controlled trials $(n=22$; $52.4 \%$ ). The sample size ranged from 17 to 2447 individuals, with $45.2 \%$ of the included studies consisting of samples with fewer than 100 participants $(n=19)$ and schoolchildren aged under 12 years (64.7\%). Most interventions were performed in schools in the southern $(40.5 \%)$ region of Brazil. Only one intervention study (with four reports) was focused on girls exclusively [28-32], and all others considered girls and boys combined. Thirteen (31.0\%) studies performed interventions based on theoretical models (e.g., socio-ecological theory or the health-promoting schools approach). A total of $30(71.4 \%), 19(45.2 \%)$, and $6(14.3 \%)$ of the included studies measured the outcomes of PA attributes, PA behavior, and modifiable PA-related factors, respectively. No study has evaluated PL using specific instruments/protocols for its assessment (Table 1).

Twenty-six intervention strategies were identified and organized into six dimensions. Interventions related to physical education classes were conducted in both age groups, which involved recreational activities with games, toys, and scavenger hunts that stimulated body movements $[27,50,69,77,80]$. Children and adolescents were provided with health education sessions such as lectures, debates, discussions, and dynamics on healthy eating, physical activity, and health $[18,19,23-33,41,42,51,54,55,61,67,69,72-74]$. In addition, there was teacher training in both student age groups $[18,22,34-40,43-49,51,60,78,79]$ (Table 2). 
3261 documents retrieved in electronic databases

Embase: 183

ERIC: 145

LILACS: 731

PsycINFO: 278

MEDLINE/PubMed: 347
SciELO: 382

Scopus: 274

SPORTDiscus: 176

Web of Science: 745
452 additional documents retrieved from secondary and complementary sources

BDTD: 152 Google Scholar: 300

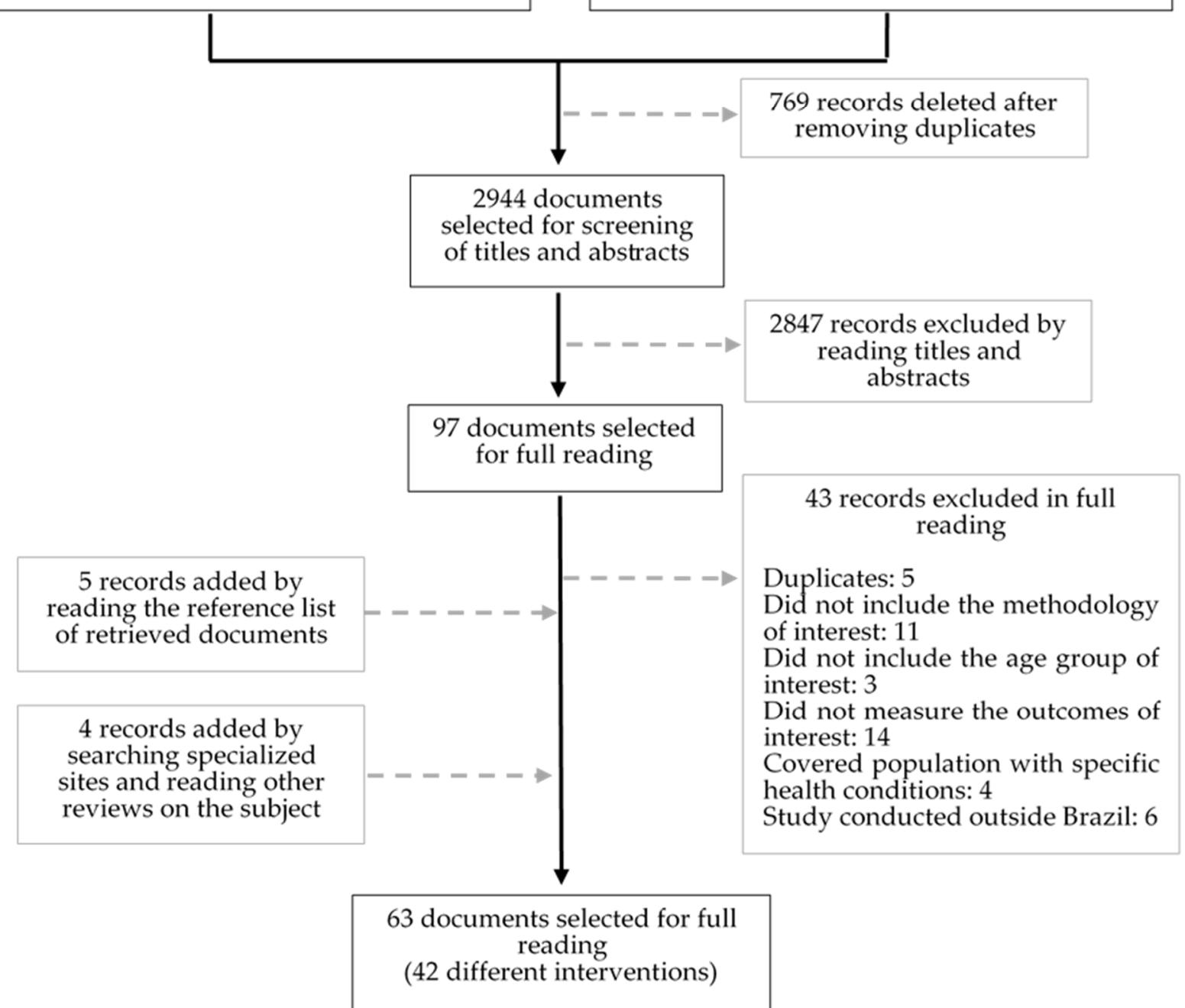

Figure 1. Flowchart of the selection process of studies (PRISMA-ScR). BDTD = Biblioteca Digital Brasileira de Teses e Dissertações (Brazil's Digital Library of Thesis and Dissertations).

Table 1. Publications and methodological characteristics of included studies according to age group.

\begin{tabular}{cccc}
\hline Variables & $\begin{array}{c}\text { All Studies } \\
\mathbf{( \% ) ~ o f ~ 4 2 )}\end{array}$ & $\begin{array}{c}\text { Studies in Children } \\
<\mathbf{1 2} \text { Years (\% of 17) }\end{array}$ & $\begin{array}{c}\text { Studies in Adolescents } \\
\mathbf{1 2} \text { Years (\% of 25) }\end{array}$ \\
\hline Year of Study & & & \\
\hline 2000-2005 & $3(7.1)$ & $1(5.9)$ & $2(8.0)$ \\
$2006-2010$ & $10(23.8)$ & $2(11.8)$ & $8(32.0)$ \\
2011-2015 & $12(28.6)$ & $3(17.6)$ & $9(36.0)$ \\
2016-June 2021 & $5(11.9)$ & $3(17.6)$ & $2(8.0)$ \\
NA & $12(28.6)$ & $8(47.1)$ & $4(16.0)$ \\
\hline
\end{tabular}


Table 1. Cont.

\begin{tabular}{|c|c|c|c|}
\hline Variables & $\begin{array}{l}\text { All Studies } \\
(\% \text { of } 42)\end{array}$ & $\begin{array}{l}\text { Studies in Children } \\
<12 \text { Years }(\% \text { of } 17)\end{array}$ & $\begin{array}{l}\text { Studies in Adolescents } \\
\geq 12 \text { Years ( } \% \text { of } 25)\end{array}$ \\
\hline \multicolumn{4}{|l|}{ Brazil's Region } \\
\hline North & $3(7.1)$ & $0(0.0)$ & $3(12.0)$ \\
\hline Northeast & $6(14.3)$ & $2(11.7)$ & $4(16.0)$ \\
\hline Midwest & $1(2.4)$ & $1(5.9)$ & $0(0.0)$ \\
\hline Southeast & $15(35.7)$ & $7(41.2)$ & $8(32.0)$ \\
\hline South & $17(40.5)$ & $7(41.2)$ & $10(40.0)$ \\
\hline \multicolumn{4}{|l|}{ Type of Study } \\
\hline RCT & $13(31.0)$ & $7(41.2)$ & $6(24.0)$ \\
\hline Cluster RCT & $9(21.4)$ & $4(23.5)$ & $5(20.0)$ \\
\hline NRCT & $16(38.1)$ & $4(23.5)$ & $12(48.0)$ \\
\hline Quasi-experimental (without control) & $4(9.5)$ & $2(11.8)$ & $2(8.0)$ \\
\hline \multicolumn{4}{|l|}{ Sample Size $(n)$} \\
\hline$>1000$ & $7(16.7)$ & $2(11.8)$ & $5(20.0)$ \\
\hline $501-1000$ & $4(9.5)$ & $1(5.9)$ & $3(12.0)$ \\
\hline $100-500$ & $12(28.6)$ & $3(17.6)$ & $9(36.0)$ \\
\hline$<100$ & $19(45.2)$ & $11(64.7)$ & $8(32.0)$ \\
\hline \multicolumn{4}{|l|}{ School Year } \\
\hline Elementary school only & $33(78.6)$ & $17(100.0)$ & $16(64.0)$ \\
\hline High school only & $8(19.0)$ & $0(0.0)$ & $8(32.0)$ \\
\hline Elementary and high school & $1(2.4)$ & $0(0.0)$ & $1(4.0)$ \\
\hline \multicolumn{4}{|l|}{ Program-based Interventions } \\
\hline Yes & $13(31.0)$ & $5(29.4)$ & $8(32.0)$ \\
\hline No & $29(69.0)$ & $12(70.6)$ & $17(68.0)$ \\
\hline \multicolumn{4}{|l|}{ Study Object } \\
\hline PA & $27(64.3)$ & $12(70.6)$ & $15(60.0)$ \\
\hline PA and healthy eating & $15(35.7)$ & $5(29.4)$ & $10(40.0)$ \\
\hline \multicolumn{4}{|l|}{ Intervention Time } \\
\hline 11-12 months & $2(4.7)$ & $0(0.0)$ & $2(8.0)$ \\
\hline 8-10 months & 7 (16.7) & $1(5.9)$ & $6(24.0)$ \\
\hline 5-7 months & $9(21.4)$ & $5(29.4)$ & $4(16.0)$ \\
\hline 2-4 months & $16(38.1)$ & $5(29.4)$ & $11(44.0)$ \\
\hline$<2$ months & $7(16.7)$ & $5(29.4)$ & $2(8.0)$ \\
\hline NA & $1(2.4)$ & $1(5.9)$ & \\
\hline \multicolumn{4}{|l|}{ Components of the Intervention } \\
\hline PL (specific instruments/protocols) & $0(0.0)$ & $0(0.0)$ & $0(0.0)$ \\
\hline PA behavior only & $7(16.7)$ & $2(11.7)$ & $5(20.0)$ \\
\hline PA behavior and associated factors & $4(9.5)$ & $0(0.0)$ & $4(16.0)$ \\
\hline PA behavior and attributes & $8(19.0)$ & $3(17.6)$ & $5(20.0)$ \\
\hline PA-associated factors only & $1(2.4)$ & $1(5.9)$ & $0(0.0)$ \\
\hline PA-associated factors and attributes & $1(2.4)$ & $0(0.0)$ & $1(4.0)$ \\
\hline PA attributes only & $21(50.0)$ & $11(64.8)$ & $10(40.0)$ \\
\hline
\end{tabular}

PA, physical activity; PL, physical literacy; RCT, randomized controlled trial; NRCT, nonrandomized controlled trial; NA, not applicable. 
Table 2. Intervention strategies and dimensions according to age groups.

\begin{tabular}{|c|c|c|c|c|c|c|}
\hline Intervention & $\begin{array}{l}\text { Physical } \\
\text { Education } \\
\text { Classes }\end{array}$ & $\begin{array}{l}\text { Changes in the } \\
\text { School } \\
\text { Environment }\end{array}$ & $\begin{array}{c}\text { Use of Electronic } \\
\text { Media as a } \\
\text { Strategy }\end{array}$ & $\begin{array}{l}\text { Extracurricular } \\
\text { PA Sessions }\end{array}$ & $\begin{array}{c}\text { Extracurricular } \\
\text { Health } \\
\text { Education } \\
\text { Sessions }\end{array}$ & $\begin{array}{l}\text { Actions Focused } \\
\text { on Family/ } \\
\text { Community }\end{array}$ \\
\hline $\begin{array}{l}\text { Children } \\
\text { (<12 years) }\end{array}$ & $\begin{array}{c}\text { Playing activities } \\
\text { that encourage } \\
\text { body movements } \\
(n=4) \\
{[27,50,77,80] ;} \\
\\
\text { Stimulation of } \\
\text { free active } \\
\text { movements } \\
\text { during physical } \\
\text { education classes } \\
(n=1)[60] .\end{array}$ & $\begin{array}{c}\text { Creation of } \\
\text { physical spaces } \\
\text { for PA } \\
(n=1)[66] ; \\
\text { Provision of sport } \\
\text { materials (e.g., } \\
\text { balls, cones, and } \\
\text { rubber bands) in } \\
\text { the school }(n=3) \\
{[56,59,76] .}\end{array}$ & & $\begin{array}{c}\text { Stretching } \\
\text { exercises, } \\
\text { resistance, sports } \\
\text { initiation games, } \\
\text { balance, fine } \\
\text { motor skills, and } \\
\text { global and } \\
\text { laterality } \\
(n=2)[69,79] ; \\
\\
\text { PA sessions with } \\
\text { activities (e.g., } \\
\text { running, jumping, } \\
\text { and dancing) or } \\
\text { opposition games } \\
(n=13)[18,21,41- \\
43,53,56- \\
61,77,80] .\end{array}$ & $\begin{array}{c}\text { Lectures and } \\
\text { educational } \\
\text { sessions on PA, } \\
\text { health, and } \\
\text { nutrition }(n=4) \\
{[27,41,42,61] ;} \\
\\
\text { Debates, } \\
\text { discussions, } \\
\text { dynamics, and } \\
\text { practical } \\
\text { experiences on PA } \\
\text { and health }(n=1) \\
{[18] .}\end{array}$ & $\begin{array}{l}\text { Faculty training } \\
\text { on PA, health, } \\
\text { and nutrition } \\
(n=3)[18,43,60] ; \\
\text { Home visit by } \\
\text { community } \\
\text { health agents } \\
(n=1) \text { [18]; } \\
\text { Consultation with } \\
\text { parents about } \\
\text { children's health } \\
\text { behaviors }(n=1) \\
\text { [27]. }\end{array}$ \\
\hline $\begin{array}{l}\text { Adolescents } \\
\text { ( } \geq 12 \text { years) }\end{array}$ & $\begin{array}{l}\text { PA sessions with } \\
\text { pranks and } \\
\text { games }(n=1) \text { [69]; } \\
\text { Warm-up } \\
\text { exercises, } \\
\text { including } \\
\text { aerobics, dynamic } \\
\text { movements, } \\
\text { stretching, and } \\
\text { relaxation }(n=25) \\
{[23-26,28-33,37-} \\
40,52,54,55,62- \\
65,70-73,79] .\end{array}$ & $\begin{array}{c}\text { Creation of } \\
\text { physical spaces } \\
\text { for PA }(n=10) \\
{[37-40,44-49,79] ;} \\
\\
\text { Provision of } \\
\text { sporting } \\
\text { materials for } \\
\text { sport practices } \\
(n=13) \\
{[22,37-40,44-} \\
49,54,68,78,79] ; \\
\\
\text { Availability of } \\
\text { booklets, } \\
\text { pamphlets, } \\
\text { posters, banners, } \\
\text { exercise guides, } \\
\text { books, and } \\
\text { handouts }(n=22) \\
{[19,22-26,28-} \\
36,44-49,51,78] .\end{array}$ & $\begin{array}{c}\text { SMS with } \\
\text { instructions and } \\
\text { motivational } \\
\text { messages on PA } \\
(n=7)[28-33,67] \\
\\
\text { Electronic diary } \\
\text { of PA and food } \\
\quad(n=1) \text { [20]; } \\
\\
\text { Dissemination of } \\
\text { educational } \\
\text { information about } \\
\text { health on an } \\
\text { electronic website } \\
(n=7)[20,44-49] .\end{array}$ & $\begin{array}{c}\text { Recreational PA } \\
\text { with hitting, } \\
\text { aerobics, and } \\
\text { relaxation }(n=2) \\
{[19,67] ;} \\
\text { Posture education } \\
\text { program }(n=2) \\
{[74,75] .}\end{array}$ & $\begin{array}{c}\text { Multiprofessional } \\
\text { approach to } \\
\text { nutrition and } \\
\text { health education } \\
(n=2)[19,67] \\
\\
\text { Lectures, } \\
\text { workshops, and } \\
\text { educational } \\
\text { sessions on PA } \\
\text { and health } \\
(n=11) \\
\text { [23-26,28-33,69]; } \\
\text { Debates, } \\
\text { discussions, } \\
\text { dynamics, and } \\
\text { practical } \\
\text { experiences on } \\
\text { behavior in PA } \\
\text { and health }(n=6) \\
\text { [51,54,55,72-74]. }\end{array}$ & $\begin{array}{c}\text { Training for } \\
\text { teachers on PA } \\
\text { and health } \\
(n=15) \\
{[22,34-40,44-} \\
49,51,78,79] ; \\
\\
\text { Provision of } \\
\text { informational } \\
\text { materials for } \\
\text { parents and } \\
\text { teachers }(n=7) \\
{[20,28-33] .}\end{array}$ \\
\hline
\end{tabular}

PA, physical activity; PL, physical literacy.

Warm-up, aerobic, isometric, dynamic, postural, strength, endurance, stretching, and relaxation exercises were more frequent in adolescents [23-26,28-33,37-40,52,54,55,62$65,67,70-75,79]$, totaling to 25 different studies. Interventions focused on playing activities (e.g., jumping, dancing, and cooperative games) were frequent in children [18,21,41$43,53,56-61,77,80]$, with 13 studies. Interventions in both children and adolescents resulted in changes in the school environment; however, with children, interventions were focused on sports materials (ropes, ball, bows, cone, mat, tape and rubber bands, and track designed with colors) $[56,59,66,68,76]$. Interventions with adolescents focused on access to booklets, pamphlets, posters, banners, and exercise guides [19,20,22-26,28-36,44-49,51,78]. Only adolescents had the opportunity to interact electronically with instructional SMS for PA practice with motivational messages about environmental changes and access to information on healthy eating habits and creation of an electronic diary of PA and food [20,28-33,44-49,67]. Some studies have explored aspects of children's motor skills $[66,76]$ and adolescents' postures [74,75]. Community health workers made home visits for children [18]. Parents were also consulted by researchers on the health behavior of their children from the intervention programs [27] (Table 2). 
Table 3 summarizes the PL investigated in the studies according to age group. The components most frequently evaluated in interventions were PA attributes [18-21,23$32,37,41,42,44,45,48,50,52-54,56-59,61-72,75,76]$ (30 studies; $71.4 \%)$. In general, children were evaluated in terms of fine and global motor skills, balance, body schema, and spatial and temporal organization $[50,56,76,80]$. Muscle and cardiorespiratory endurance have been investigated more in adolescents [23-26,44,45,48,52-54,70-72] than in children $[27,57,66]$. Flexibility, physical and cardiorespiratory fitness, agility, BMI, weight, and height were variables assessed in both age groups [18-20,23-33,41,42,62,64-67,69,72]. Most studies evaluated PL components and reported that the intervention had an effect on them $[20,21,27,41,42,50,53,54,56-59,61-66,69-72,75,76]$ (Table 3).

Table 3. Components of PL investigated in the studies according to the age group.

\begin{tabular}{|c|c|c|c|c|c|}
\hline \multirow[b]{2}{*}{$\begin{array}{c}\text { Components of } \\
\text { PL }\end{array}$} & \multirow[b]{2}{*}{ Variables } & \multicolumn{2}{|c|}{ Children ( $<12$ years) } & \multicolumn{2}{|c|}{ Adolescents ( $\geq 12$ years) } \\
\hline & & $\begin{array}{l}\text { Studies that } \\
\text { Evaluated the } \\
\text { Component }\end{array}$ & $\begin{array}{l}\text { Studies that } \\
\text { Reported the } \\
\text { Effect of the } \\
\text { Intervention }\end{array}$ & $\begin{array}{l}\text { Studies that } \\
\text { Evaluated the } \\
\text { Component }\end{array}$ & $\begin{array}{l}\text { Studies that } \\
\text { Reported the } \\
\text { Effect of the } \\
\text { Intervention }\end{array}$ \\
\hline \multicolumn{6}{|l|}{$\begin{array}{l}\text { PA-Associated } \\
\text { Factors }\end{array}$} \\
\hline \multirow{7}{*}{$\begin{array}{l}\text { Psychological } \\
\text { Domain }\end{array}$} & $\begin{array}{c}\text { Posture } \\
\text { self-perception }\end{array}$ & & & [75] & [75] \\
\hline & Body perception & & & [19] & \\
\hline & Self-esteem & [77] & [77] & {$[19,23-26]$} & \\
\hline & Self-efficacy for PA & & & $\begin{array}{c}{[22-26,28-33,37-} \\
40,78,79]\end{array}$ & \\
\hline & $\begin{array}{l}\text { Perception of the } \\
\text { environment } \\
\text { for PA }\end{array}$ & & & $\begin{array}{c}{[22-26,28-33,37-} \\
40,78,79]\end{array}$ & \\
\hline & Satisfaction for PA & & & [22] & \\
\hline & Attitude for PA & & & {$[23-26,37-40,79]$} & [37-39] \\
\hline \multirow{3}{*}{$\begin{array}{c}\text { Socio- } \\
\text { Environmental } \\
\text { Domain }\end{array}$} & $\begin{array}{l}\text { Parental support } \\
\quad \text { for PA }\end{array}$ & & & {$[22,28-33,37-40]$} & [37-39] \\
\hline & $\begin{array}{l}\text { Support from } \\
\text { friends for PA }\end{array}$ & & & {$[22,37-40]$} & [37-39] \\
\hline & $\begin{array}{l}\text { Teacher support } \\
\text { for PA }\end{array}$ & & & {$[37-40]$} & [37-39] \\
\hline \multirow[b]{2}{*}{ Cognitive Domain } & PA knowledge & [60] & & {$[22,34-36,51]$} & {$[34-36]$} \\
\hline & $\begin{array}{l}\text { Physical attitude } \\
\text { knowledge }\end{array}$ & [60] & & & \\
\hline \multirow{3}{*}{ PA } & $\begin{array}{l}\text { PA level (active, } \\
\text { insufficiently } \\
\text { active, or inactive) }\end{array}$ & [18] & [18] & {$[51,55,63]$} & [51] \\
\hline & PA practice & {$[43,60,61]$} & {$[43,60,61]$} & $\begin{array}{c}23-26,28-40,44- \\
49,63,67,73,74]\end{array}$ & {$[44-49,73,74]$} \\
\hline & Time spent in PA & & & {$[44-49,73,74]$} & [74] \\
\hline
\end{tabular}


Table 3. Cont.

\begin{tabular}{|c|c|c|c|c|c|}
\hline \multirow[b]{2}{*}{$\begin{array}{c}\text { Components of } \\
\text { PL }\end{array}$} & \multirow[b]{2}{*}{ Variables } & \multicolumn{2}{|c|}{ Children (<12 years) } & \multicolumn{2}{|c|}{ Adolescents ( $\geq 12$ years) } \\
\hline & & $\begin{array}{l}\text { Studies that } \\
\text { Evaluated the } \\
\text { Component }\end{array}$ & $\begin{array}{l}\text { Studies that } \\
\text { Reported the } \\
\text { Effect of the } \\
\text { Intervention }\end{array}$ & $\begin{array}{l}\text { Studies that } \\
\text { Evaluated the } \\
\text { Component }\end{array}$ & $\begin{array}{l}\text { Studies that } \\
\text { Reported the } \\
\text { Effect of the } \\
\text { Intervention }\end{array}$ \\
\hline \multirow{17}{*}{ PA Attributes } & Fine motors skills & {$[50,56,76,80]$} & {$[50,56,76,80]$} & & \\
\hline & Global motor skills & {$[50,56,76,80]$} & {$[50,56,76,80]$} & & \\
\hline & Locomotor skills & [53] & [53] & [68] & \\
\hline & Body scheme & {$[50,56,76]$} & [76] & & \\
\hline & $\begin{array}{c}\text { Spatial } \\
\text { organization }\end{array}$ & {$[50,76]$} & [76] & & \\
\hline & $\begin{array}{c}\text { Temporal } \\
\text { organization }\end{array}$ & {$[50,76]$} & [76] & & \\
\hline & $\begin{array}{l}\text { General physical } \\
\text { fitness }\end{array}$ & {$[21,27,59,61]$} & {$[59,61]$} & {$[63,65]$} & {$[63,65]$} \\
\hline & $\begin{array}{l}\text { Cardiorespiratory } \\
\text { fitness }\end{array}$ & [66] & [66] & {$[23-26,54,71,72]$} & {$[54,71,72]$} \\
\hline & Balance & {$[50,56,76]$} & {$[50,56,76]$} & & \\
\hline & Muscle endurance & {$[27,57,66]$} & {$[27,57,66]$} & {$[44,45,48,52,53,70-72]$} & {$[52,53,70-72]$} \\
\hline & Flexibility & {$[57,58,66]$} & {$[57,58,66]$} & {$[54,70-72]$} & {$[54,70-72]$} \\
\hline & Agility & [21] & [21] & [71] & [71] \\
\hline & Posture & & & [75] & [75] \\
\hline & Velocity & [21] & [21] & & \\
\hline & BMI & {$[18,27,41,42,66]$} & {$[27,41,42]$} & $\begin{array}{c}{[19,20,23-26,28-} \\
33,62,64,65,67,69,72]\end{array}$ & {$[20,62,64,69]$} \\
\hline & Weight & {$[18,27,41,42,66]$} & {$[27,41,42]$} & $\begin{array}{c}{[19,20,23-26,28-} \\
33,62,64,65,67,69,72]\end{array}$ & {$[20,62,64,69]$} \\
\hline & Height & {$[18,27,41,42,66]$} & {$[27,41,42]$} & $\begin{array}{c}{[19,20,23-26,28-} \\
33,62,64,65,67,69,72]\end{array}$ & {$[20,62,64,69]$} \\
\hline
\end{tabular}

PL, physical literacy; PA, physical activity; BMI, body mass index. The components of PL were operationalized in modifiable PA-related factors (e.g., motivation, self-efficacy, interpersonal support, and environmental factors), PA behavior (e.g., the weekly volume of PA), and PA attributes (e.g., physical fitness, motor behavior, and between others) [3,6].

Of the 42 studies, 19 evaluated PA behavior, with more studies involving adolescents $[18,23-26,28-34,37-40,43-49,51,55,60,61,63,67,73,74]$ than children $[18,43,60,61]$. The total duration of PA and moderate-to-intense PA practices was observed in both populations. Active commuting to/from school $[44-49,73,74]$ was evaluated only in adolescents. Despite the purpose of evaluating the behavioral component of PA, 13 studies did not report the effect of the intervention $[18,43-49,51,60,61,73,74]$ (Table 3).

PA-related factors were evaluated with children in only two studies [60,77]; however, 12 studies with adolescents reported results on them [19,22-26,28-33,37-40,51,75]. The psychological domain related to body perception, self-esteem, self-efficacy, perception of the environment, and satisfaction with PA was evaluated; however, several studies did not report any effect of these outcomes in adolescents $[19,22-26,28-33,40,51]$. Studies have reported a significantly positive effect on self-perception of posture [75] and PA attitude [37-39]. Nevertheless, the social domain has been exclusively studied among adolescents [22,28-33,37-40], with a positive association of the support indicator of parents, friends, and teachers [37-39]. Finally, knowledge on PA was assessed in children and adolescents, with an effect reported only in the latter age group [34-36]. The positive 
effect of intervention on PA-related factors has been reported only in a few studies with adolescents [34,36-39,75] (Table 3).

\section{Discussion}

\subsection{Summary of Evidence}

In the present review, 42 different intervention studies were conducted with Brazilian school-aged children and adolescents over more than two decades, with the aim of promoting PA and/or other PL components (mainly PA attributes, such as physical fitness). However, none of them evaluated PL using a specific method (i.e., using specific instruments and protocols) that addressed all PL components or different parts of them. Studies on PL have increased in high-income countries over the last few years, particularly with measurement and intervention models to promote the relevant components of individual and population health status [81]. However, our results reinforce the results of previous reviews that highlighted insufficient evidence on interventions for PA and/or PL in children and adolescents from low- and middle-income countries, such as Brazil [10,11]. Considering that the WHO highlights that PL is an objective of the global PA action plan [1], studies on this topic are urgent, particularly on the literature gaps highlighted in this review.

Most of the included interventions focused on PA attributes, such as physical fitness $[18-21,23-33,41,42,44,45,48-50,52,53,56-59,61-72,75,76]$. PA attributes related to motor competence were components studied only in children, such as motor/locomotor skills, body scheme, and balance; cardiorespiratory fitness, resistance, flexibility, and anthropometric indicators were components evaluated mainly in adolescents. Interventions should consider the physiological development and psychomotricity principles of each phase of life $[2,16]$ because PA attributes are agents that offer physical and motor components for regular and diverse practices in PA [6]. However, Whitehead [2] argues that components of the psychological, social, and cognitive domains are fundamental to promoting individuals PL. Thus, it is important to investigate PA attributes at all stages of life in combination with PA practice and other PL components to deepen the psychosocial and behavioral aspects of PL [15].

The present review found that only six of the 42 interventions analyzed components of the dimension of PA-related factors [19,22-26,28-33,37-40,44-49,60,75]. In particular, PA-related factors and behaviors have been insufficiently studied in populations under 12 years of age. The literature recognizes that measuring exposures or outcomes in children can be challenging $[82,83]$. Assessing the PL has a pertinent health value; however, it is an aspect that faces challenges, making it necessary to take a delicate look at this broad field, particularly on the socio-environmental aspects that are as important as physical characteristics that facilitate the inclusion of individuals in the context of body movement and, consequently, in PA $[6,15,84]$. Thus, researchers have revealed the need to enhance tools and approaches that improve the measurement of PL, as tools have been created and improved to cover the entire PL without the detriment of any component $[7,85]$. The health of younger individuals is a wide field to be explored, and this review points to this gap to be improved.

Few studies have reported success in significantly promoting PA-related factors in adolescents; these components were less investigated, and of the existing studies, few reported an effect. One of the studies that addressed these topics was the "Fortaleza sua Saúde" program, a multicomponent intervention based on the Health Promoting Schools approach that found positive effects in attitude toward PA and parental, friends, and teachers' support for PA [37-39]. Although a systematic review of interventions from highincome countries found positive effects in modifiable PA factors in the young population [8], our results suggest that intervention strategies in Brazil need to be improved to achieve positive effects on these PL components. These components are essential for promoting active individuals and societies [1].

Changes in physical education classes were the main strategies implemented in interventions [23-33,37-40,50,52,54,55,60,62-65,69-73], followed by extracurricular exercise 
sessions $[18,19,21,41-43,53,56-59,61,66,67,74-76]$. Both strategies have been recognized as effective strategies to promote physical components of PL, such as physical fitness and motor behavior $[86,87]$. Other studies focused on extracurricular health education sessions $[18,19,23,27,33,41,42,51,54,55,61,67,69,72-74]$ and teachers' training on PA and health content in the curriculum $[18,22,34-40,43-49,51,60]$, which were relevant strategies to address knowledge and attitudes on PA and health. We also highlighted the number of studies that focused on social and environmental changes in schools [19,22-26,28-40,44$49,51,54,56,59,66,68,76]$. This is important because for a school to be a health-promoting environment, the school environment must promote the dissemination of information through its inclusion into the school curriculum, including knowledge and experiences that enable autonomy, well-being, and health [88].

Only three Brazilian interventions have focused on strategies that involve family members [20,27-33]. Although the importance of the family through the construction and consolidation of PL components, particularly in children, strategies that involve the family and school context seem to be a challenge at a large scale, mainly because the difficulties involve parents and the family in the intervention process and behavioral change [89,90].

\subsection{Practical and Research Implications of the Review}

To the best of our knowledge, this is the first review to synthesize information about the various components of PL. Thus, an agenda of research priorities for interventions in Brazilian schools can be identified based on the findings of this review:

- Interventions with strategies that focus on the principles and components of PL (i.e., motivation, confidence, physical competence, knowledge, and understanding to maintain PA throughout life) should be planned and implemented, which may help understand which strategies should be implemented to promote PL components and how they interfere with PA and health outcomes. This helps build evidence on the direct and indirect effects of PL on PA and health at the population level [6].

- Studies should prioritize the use of measurement protocols and instruments that broadly examine PL components because this review showed that no intervention simultaneously addressed behavior, associated factors, and attributes.

- Studies should be planned to evaluate the intervention effectiveness of modifiable PA factors, considering the psychological, socio-environmental, and cognitive domains of PA. The current literature provides limited evidence on this topic.

- Studies with school-aged children under 12 years of age are stimulated, which propose intervention strategies and the evaluation outcomes related to PA behaviors and modifiable PA factors, using reliable and validated instruments and techniques (e.g., direct observation of accelerometer-measured PA).

- Studies with gender-specific results on the implementation and effectiveness are relevant to understand whether the intervention process and results are different between boys and girls.

- Several studies have measured the intervention effect on PA behaviors or attributes (particularly physical fitness and BMI). Thus, a synthesis that evaluates the evidence quality (i.e., risk of bias and evidence level based on a systematic review approach) may be conducted, which is important for defining the effectiveness of school-based interventions on these outcomes.

- Studies that focus on the feasibility and implementation process of the different types of school-based intervention strategies of PA and PL components are stimulated, including strategies that are frequently used (e.g., extracurricular exercise sessions or teachers' training) and those that are innovative (e.g., electronic media interventions). This may be used by politicians, professionals, managers, and society to understand the barriers and facilitators of the different strategies, helping them adapt according to individual, social, and contextual features. 


\section{Conclusions}

This review found 63 documents related to 42 different intervention studies conducted with Brazilian schoolchildren. However, there are no intervention studies that cover all PL components in the same study. The strategies most used in the interventions were changes in physical education classes, health education sessions, and extracurricular PA sessions. Adolescents were observed with a greater number of interventions. The most studied PL was related to PA attributes, in contrast to the factors associated with PA in its psychological, socio-environmental, and cognitive domains, which were the least investigated components. This review highlighted gaps in the literature and the need to conduct interventions with strategies that target all components of PL, representing important elements for a research agenda that underlies school interventions that contribute to an active lifestyle.

Supplementary Materials: The following are available online at https:/ /www.mdpi.com/article/ 10.3390/ijerph18168349/s1, Table S1: Preferred Reporting Items for Systematic reviews and MetaAnalyses extension for Scoping Reviews (PRISMA-ScR) Checklist; Table S2: Searching Results; Table S3: Searching Strategy Implemented at Medline (Pubmed Portal); Table S4: Searching Strategy Implemented at Gray Literature Databases. Brazilian Digital Library of Theses and Dissertations (BDTD).

Author Contributions: Conceptualization, V.C.B.F. and W.M.G.P.; methodology, V.C.B.F., W.M.G.P., K.S.S. and P.H.G.; validation, V.C.B.F., K.S.S., P.H.G. and T.M.M.M.; formal analysis, V.C.B.F., K.S.S. and P.H.G.; investigation, V.C.B.F., W.M.G.P., V.H.S.d.C. and B.d.O.F.; data curation, V.C.B.F. and W.M.G.P.; writing —original draft preparation, V.C.B.F. and W.M.G.P.; writing—review and editing, V.C.B.F., W.M.G.P., K.S.S., P.H.G., T.M.M.M., B.d.O.F., A.C.M.Q. and V.H.S.d.C.; visualization, V.C.B.F., W.M.G.P., K.S.S., P.H.G., T.M.M.M., B.d.O.F., A.C.M.Q. and V.H.S.d.C.; supervision, V.C.B.F. and W.M.G.P.; project administration, V.C.B.F. and W.M.G.P. All authors have read and agreed to the published version of the manuscript.

Funding: This study received no funding for its implementation. Some authors received individual grants from the Coordenação de Aperfeiçoamento de Pessoal de Nível Superior-Brasil Finance Code 001 (W.M.G.P., N. 88882.447540/2019-01; V.H.S.d.C., N. 88887.473351/2020-00). The funding agencies did not participate in the interpretation, analysis, writing, or approval of this manuscript.

Conflicts of Interest: The authors declare no conflict of interest.

\section{References}

1. World Health Organization. Global Action Plan on Physical Activity 2018-2030: More Active People for a Healthier World; World Health Organization: Geneva, Switzerland, 2019.

2. Whitehead, M. Physical Literacy across the World; Routledge: Oxfordshire, UK, 2019.

3. Cairney, J.; Clark, H.; Dudley, D.; Kriellaars, D. Physical Literacy in Children and Youth-A Construct Validation Study. J. Teach. Phys. Educ. 2019, 38, 84-90. [CrossRef]

4. Gabriel, K.K.P.; Morrow, J.R.; Woolsey, A.-L.T. Framework for Physical Activity as a Complex and Multidimensional Behavior. J. Phys. Act. Health 2012, 9, S11-S18. [CrossRef]

5. Bauman, A.E.; Reis, R.S.; Sallis, J.F.; Wells, J.C.; Loos, R.J.; Martin, B.W.; Group, L.P.A.S.W. Correlates of Physical Activity: Why Are Some People Physically Active and Others Not? Lancet 2012, 380, 258-271. [CrossRef]

6. Cairney, J.; Dudley, D.; Kwan, M.; Bulten, R.; Kriellaars, D. Physical Literacy, Physical Activity and Health: Toward an EvidenceInformed Conceptual Model. Sports Med. 2019, 49, 371-383. [CrossRef] [PubMed]

7. Sheehan, D. Physical Literacy Assessment around the World. J. Health Phys. Educ. Counc. Alta. Teach. Assoc. 2018, 49, $21-23$.

8. Demetriou, Y.; Höner, O. Physical Activity Interventions in the School Setting: A Systematic Review. Psychol. Sport Exerc. 2012, 13, 186-196. [CrossRef]

9. Aubert, S.; Barnes, J.D.; Abdeta, C.; Nader, P.A.; Adeniyi, A.F.; Aguilar-Farias, N.; Tenesaca, D.S.A.; Bhawra, J.; Brazo-Sayavera, J.; Cardon, G. Global Matrix 3.0 Physical Activity Report Card Grades for Children and Youth: Results and Analysis from 49 Countries. J. Phys. Act. Health 2018, 15, S251-S273. [CrossRef] [PubMed]

10. Da Silva, J.A.; Gonçalves, E.C.D.A.; Silva, D.A.S.; Silva, K.S. Programas de Intervenção Para Atividade Física Nas Escolas Brasileiras: Revisão Com Base No Modelo RE-AIM. Ciênc. Saúde Colet. 2019, 24, 3443-3456. [CrossRef]

11. Filho, V.C.B.; Minatto, G.; Mota, J.; Silva, K.S.; de Campos, W.; Lopes, A.d.S. Promoting Physical Activity for Children and Adolescents in Low-and Middle-Income Countries: An Umbrella Systematic Review: A Review on Promoting Physical Activity in LMIC. Prev. Med. 2016, 88, 115-126. [CrossRef] 
12. De Souza, E.A.; Filho, V.C.B.; Nogueira, J.A.D.; De Azevedo Júnior, M.R. Atividade Física e Alimentação Saudável Em Escolares Brasileiros: Revisão de Programas de Intervenção. Cad. Saúde Pública 2011, 27, 1459-1471. [CrossRef]

13. Peters, M.D.J.; Godfrey, C.; McInerney, P.; Munn, Z.; Tricco, A.C.; Khalil, H. Chapter 11: Scoping Reviews. In JBI Manual for Evidence Synthesis. Available online: https:/ / synthesismanual.jbi.global (accessed on 28 July 2021).

14. Tricco, A.C.; Lillie, E.; Zarin, W.; O’Brien, K.K.; Colquhoun, H.; Levac, D.; Moher, D.; Peters, M.D.J.; Horsley, T.; Weeks, L.; et al. PRISMA Extension for Scoping Reviews (PRISMA-ScR): Checklist and Explanation. Ann. Intern. Med. 2018, 169, 467-473. [CrossRef] [PubMed]

15. Keegan, R.J.; Barnett, L.M.; Dudley, D.A.; Telford, R.D.; Lubans, D.R.; Bryant, A.S.; Roberts, W.M.; Morgan, P.J.; Schranz, N.K.; Weissensteiner, J.R.; et al. Defining Physical Literacy for Application in Australia: A Modified Delphi Method. J. Teach. Phys. Educ. 2019, 38, 105-118. [CrossRef]

16. Schubert, A.; Januário, R.S.B.; Casonatto, J.; Sonoo, C.N. Aptidão Física Relacionada à Prática Esportiva Em Crianças e Adolescentes. Rev. Bras. Med. Esporte 2016, 22, 142-146. [CrossRef]

17. Hoehner, C.M.; Ribeiro, I.C.; Parra, D.C.; Reis, R.S.; Azevedo, M.R.; Hino, A.A.; Soares, J.; Hallal, P.C.; Simões, E.J.; Brownson, R.C. Physical Activity Interventions in Latin America: Expanding and Classifying the Evidence. Am. J. Prev. Med. 2013, 44, e31-e40. [CrossRef] [PubMed]

18. Sgambato, M.R.; Cunha, D.B.; Souza, B.S.N.; Henriques, V.T.; Rodrigues, R.R.M.; Rêgo, A.L.V.; Pereira, R.A.; Yokoo, E.M.; Sichieri, R. Effectiveness of School-Home Intervention for Adolescent Obesity Prevention: Parallel School Randomised Study. Br. J. Nutr. 2019, 122, 1073-1080. [CrossRef]

19. Dunker, K.L.L.; Claudino, A.M. Preventing Weight-Related Problems among Adolescent Girls: A Cluster Randomized Trial Comparing the Brazilian 'New Moves' Program versus Observation. Obes. Res. Clin. Pract. 2017, 12, 102-115. [CrossRef]

20. Da Silva, K.B.B.; Ortelan, N.; Murta, S.G.; Sartori, I.; Couto, R.D.; Fiaccone, R.L.; Barreto, M.L.; Bell, M.J.; Taylor, C.B.; Ribeiro-Silva, R.d.C. Evaluation of the Computer-Based Intervention Program Stayingfit Brazil to Promote Healthy Eating Habits: The Results from a School Cluster-Randomized Controlled Trial. IJERPH 2019, 16, 1674. [CrossRef]

21. Da Silva, H.V.A.; do Nascimento, T.A.; de Lima, T.M.; Costa, A.d.S. The Effect of an Initiation to Struggles Structured Program on the Physical Capacities, Visual Attention and School Performance in Elementary School Children. Rev. Bras. Ciênc. Esporte 2019, 41, 176-182. [CrossRef]

22. Knebel, M.T.G.; Borgatto, A.F.; Lopes, M.V.V.; Santos, P.C.; Matias, T.S.; Narciso, F.V.; Silva, K.S. Mediating Role of Screen Media Use on Adolescents' Total Sleep Time: A Cluster-randomized Controlled Trial for Physical Activity and Sedentary Behaviour. Child. Care Health Dev. 2020, 46, 381-389. [CrossRef]

23. Da Costa, B.G.G.; da Silva, K.S.; da Silveira, P.M.; Berria, J.; Machado, A.R.; Petroski, E.L. Efeito de uma intervenção sobre atividade física moderada a vigorosa e comportamento sedentário no tempo escolar de adolescentes. Rev. Bras. Epidemiol. 2019, 22, e190065. [CrossRef]

24. Vieira, J.A.J.; de Lima, L.R.A.; Silva, D.A.S.; Petroski, E.L. Effectiveness of a Multicomponent Intervention on the Screen Time of Brazilian Adolescents: Non-Randomized Controlled Study. Mot. Rev. Educ. Fís. 2018, 24. [CrossRef]

25. Minatto, G.; Petroski, E.; Silva, K.; Duncan, M. School-Based Intervention on Cardiorespiratory Fitness in Brazilian Students: A Nonrandomized Controlled Trial. J. Funct. Morphol. Kinesiol. 2019, 4, 10. [CrossRef]

26. Berria, J.; Minatto, G.; Lima, L.R.; Martins, C.R.; Petroski, E.L. Predictors of Dropout in the School-Based Multi-Component Intervention, "Mexa-Se". Health Educ. Res. 2018, 33, 280-291. [CrossRef] [PubMed]

27. Hulshof, V.A. Aptidão Física Relacionada à Saúde de Alunos do Ensino Fundamental Participantes de Programas para Mudanças do Estilo de Vida Na Escola. Master's Dissertation, Faculdade de Medicina de Botucatu, São Paulo State University, São Paulo, Brazil, 2012.

28. Leme, A.C.B. Hábitos Saudáveis, Meninas Saudáveis-Brasil um Ensaio Comunitário Randomizado Controlado: Prevenindo a Obesidade entre Adolescentes do Município de São Paulo. Ph.D. Thesis, Universidade de São Paulo, São Paulo, Brazil, 2015.

29. Leme, A.C.B.; Baranowski, T.; Thompson, D.; Nicklas, T.; Philippi, S.T. Sustained Impact of the "Healthy Habits, Healthy Girls-Brazil" School-Based Randomized Controlled Trial for Adolescents Living in Low-Income Communities. Prev. Med. Rep. 2018, 10, 346-352. [CrossRef] [PubMed]

30. Leme, A.C.B.; Lubans, D.R.; Guerra, P.H.; Dewar, D.; Toassa, E.C.; Philippi, S.T. Preventing Obesity among Brazilian Adolescent Girls: Six-Month Outcomes of the Healthy Habits, Healthy Girls-Brazil School-Based Randomized Controlled Trial. Prev. Med. 2016, 86, 77-83. [CrossRef] [PubMed]

31. Leme, A.C.B.; Philippi, S.T. The "Healthy Habits, Healthy Girls" Randomized Controlled Trial for Girls: Study Design, Protocol, and Baseline Results. Cad. Saúde Pública 2015, 31, 1381-1394. [CrossRef]

32. Leme, A.C.B.; Philippi, S.T.; Thompson, D.; Nicklas, T.; Baranowski, T. "Healthy Habits, Healthy Girls-Brazil": An Obesity Prevention Program with Added Focus on Eating Disorders. Eat. Weight. Disord. Stud. Anorex. Bulim. Obes. 2019, 24, 107-119. [CrossRef]

33. Da Silva, E.C.T. Hábitos Saudáveis, Meninas Saudáveis: Estratégia de Intervenção em Alimentação Saudável e Refeições em Família de Adolescentes de Escolas Técnicas. Ph.D. Thesis, Universidade de São Paulo, São Paulo, Brazil, 2015.

34. Fortes, M.d.O. Efetividade de uma Intervenção Escolar para Promoção de Atividade Física e Saúde. Master's Dissertation, Universidade Federal de Pelotas, Pelotas, Brazil, 2013. 
35. Spohr, C.; Fortes, M.; Rombaldi, A.; Hallal, P.; Azevedo, M. Atividade física e saúde na Educação Física escolar: Efetividade de um ano do projeto "Educação Física +". Rev. Bras. Ativ. Fis. Saude 2014, 19, 300. [CrossRef]

36. Gonzales, N.G.; Azevedo, M.R.; Böhlke, C.F.; Freitas, M.P.; Rombaldi, A.J. PROJETO EF+: Implicações pedagógicas e nível de conhecimento sobre saúde. J. Phys. Educ. 2018, 29. [CrossRef]

37. Filho, V.C.B.; Bandeira, A.; Minatto, G.; Linard, J.; Silva, J.; Costa, R.; Manta, S.; Sá, S.; Matias, T.; Silva, K. Effect of a Multicomponent Intervention on Lifestyle Factors among Brazilian Adolescents from Low Human Development Index Areas: A Cluster-Randomized Controlled Trial. IJERPH 2019, 16, 267. [CrossRef]

38. Filho, V.C.B.; da Silva, K.S.; Mota, J.; Beck, C.; Lopes, A.d.S. A Physical Activity Intervention for Brazilian Students from Low Human Development Index Areas: A Cluster-Randomized Controlled Trial. J. Phys. Act. Health 2016, 13, 1174-1182. [CrossRef]

39. Filho, V.C.B.; da Silva, K.S.; Mota, J.; Vieira, N.F.C.; Gubert, F.d.A.; Lopes, A.d.S. “For Whom Was It Effective?" Moderators of the Effect of a School-Based Intervention on Potential Physical Activity Deter-minants among Brazilian Students. Prev. Med. 2017, 97, 80-85. [CrossRef] [PubMed]

40. Filho, V.C.B.; Lopes, A.d.S.; Lima, A.B.; de Souza, E.A.; Gubert, F.d.A.; Silva, K.S.; Vieira, N.F.C.; Filho, N.T.; de Araújo, T.S.; de Bruin, P.F.C.; et al. Rationale and Methods of a Cluster-Randomized Controlled Trial to Promote Active and Healthy Lifestyles among Brazilian Students: The "Fortaleça Sua Saúde" Program. BMC Public Health 2015, 15, 1212. [CrossRef]

41. Friedrich, R.R.; Caetano, L.C.; Schiffner, M.D.; Wagner, M.B.; Schuch, I. Design, Randomization and Methodology of the TriAtiva Program to Reduce Obesity in School Children in Southern Brazil. BMC Public Health 2015, 15, 363. [CrossRef]

42. Friedrich, R.R. Efeito de Um Programa de Intervenção Com Educação Nutricional e Atividade Física Na Prevenção Da Obesidade Em Escolares: Um Estudo Controlado Randomizado. Ph.D. Thesis, Universidade Federal do Rio Grande do Sul, Porto Alegre, Brazil, 2015.

43. Ribeiro, R.Q.; Alves, L. Comparison of Two School-Based Programmes for Health Behaviour Change: The Belo Horizonte Heart Study Randomized Trial. Public Health Nutr. 2014, 17, 1195-1204. [CrossRef] [PubMed]

44. Filho, V.C.B.; da Silva, K.S.; Rech, C.R.; Brito, A.L.S.; de Oliveira, E.S.A.; Nahas, M.V. Mudanças no estilo de vida e na percepção da saúde em estudantes do ensino médio: Análise prospectiva do projeto "Saúde na Boa". Rev. Bras. Cineantropometria Desempenho Hum. 2014, 16, 55. [CrossRef]

45. Del Duca, G.F.; de Barros, M.V.G.; Silva, K.S.; Garcia, L.M.T.; Bezerra, J.; Nahas, M.V. Efetividade Em Indicadores de Atividade Física de Uma Intervenção Com Estudantes Do Ensino Médio. Rev. Bras. Cineantropometria Desempenho Hum. 2014, 16, 13-24. [CrossRef]

46. Hardman, C.M.; de Barros, M.V.G.; Lopes, A.S.; Lima, R.A.; Bezerra, J.; Nahas, M.V. Effectiveness of a school-based intervention regarding screen time in high school students. Rev. Bras. Cineantropometria Desempenho Hum. 2014, 16, 25. [CrossRef]

47. Silva, K.S.; de Barros, M.V.G.; Filho, V.C.B.; Garcia, L.M.T.; Wanderley, R.D.S., Jr.; Beck, C.C.; Nahas, M.V. Implementação da intervenção "Saúde na Boa": Avaliação de processo e características dos estudantes permanecentes e não permanecentes. Rev. Bras. Cineantropometria Desempenho Hum. 2014, 16, 1-12. [CrossRef]

48. de Barros, M.V.G.; Nahas, M.V.; Hallal, P.C.; de Farias Júnior, J.C.; Florindo, A.A.; de Barros, S.S.H. Effectiveness of a SchoolBased Intervention on Physical Activity for High School Students in Brazil: The Saude Na Boa Project. J. Phys. Act. Health 2009, 6, 163-169. [CrossRef]

49. Nahas, M.V.; de Barros, M.V.G.; de Assis, M.A.A.; Hallal, P.C.; Florindo, A.A.; Konrad, L. Methods and Participant Characteristics of a Randomized Intervention to Promote Physical Activity and Healthy Eating Among Brazilian High School Students: The Saude Na Boa Project. J. Phys. Act. Health 2009, 6, 153-162. [CrossRef]

50. Dos Anjos, I.d.V.C.; Ferraro, A.A. A Influência Da Dança Educativa No Desenvolvimento Motor de Crianças. Rev. Paul. Pediatr. 2018, 36, 337-344. [CrossRef]

51. De Barros, M.V.G. Atividades Físicas e Padrão de Consumo Alimentar em Estudantes do Ensino Médio em Santa Catarina. Ph.D. Thesis, Universidade Federal do Rio Grande do Sul, Porto Alegre, Brazil, 2004.

52. Braga, P. Desenvolvimento de Força em Crianças e Jovens nas Aulas de Educação Física. Master's Dissertation, Universidade Federal do Rio Grande do Sul, Porto Alegre, Brazil, 2007.

53. Braga, R.; Ruy, J.; Tkac, C.; Valentini, N. Influência de um Programa de Intervenção Motora No Desempenho das Habilidades Locomotoras de Crianças Com Idade Entre 6 e 7 Anos. Rev. Educ. Fís. UEM 2009, 20, 171-181. [CrossRef]

54. Braga, F.C.C. Avaliação de Um Programa de Educação Física Escolar Sobre Os Hábitos de Vida/Alimentar e Aptidão Física Relacionada à Saúde. Ph.D. Thesis, Universidade Federal do Rio Grande do Sul, Porto Alegre, Brazil, 2016.

55. Brito, A.K.A.; Lopes, F.; Júnior, S. Efeitos de Uma Intervenção Na Educação Física Escolar, Sobre Parâmetros Relacionados à Saúde, Em Escolares-Estudo Piloto. Pediatr. Mod. 2012, 14, 461-467.

56. Cardeal, C.M.; Pereira, L.A.; Silva, P.F.; França, N.M. Efeito de um programa escolar de estimulação motora sobre desempenho da função executiva e atenção em crianças. Motricidade 2013, 9, 44-56. [CrossRef]

57. Coledam, D.H.C.; de Arruda, G.A.; de Oliveira, A.R. Efeitos de um programa de exercícios no desempenho de crianças nos testes de flexibilidade e impulsão vertical. Mot. Rev. Educ. Fis. 2012, 18, 515-525. [CrossRef]

58. Coledam, D.H.C.; de Arruda, G.A.; de Oliveira, A.R. Efeito crônico do alongamento estático realizado durante o aquecimento sobre a flexibilidade de crianças. Rev. Bras. Cineantropometria Desempenho Hum. 2015, 14, 296-304. [CrossRef]

59. Costa, C.L.A.; Nobre, G.C.; Nobre, F.S.S.; Valentini, N.C. Efeito de um programa de intervenção motora sobre o desenvolvimento motor de crianças em situação de risco social na re-gião do Cariri-Ceará. Rev. Educ. Fís. UEM 2014, 25, 353. [CrossRef] 
60. Da Cunha, C.T.; Poblacion, A.P.; Colugnati, F.A.B.; Taddei, J.A.d.A.C.; Bracco, M.M. Effect of an Educational Program on Schoolchildren's Energy Expenditure during Physical Education Classes. Med. Express 2016, 3. [CrossRef]

61. Da Silva, L.S.M.; Fisberg, M.; Pires, M.M.D.S.; Nassar, S.; Sottovia, C. The Effectiveness of a Physical Activity and Nutrition Education Program in the Prevention of Overweight in Schoolchildren in Criciúma, Brazil. Eur. J. Clin. Nutr. 2013, 67, 1200-1204. [CrossRef]

62. Farias, E.S.; Paula, F.; Carvalho, W.R.; Gonçalves, E.M.; Baldin, A.D.; Guerra, G., Jr. Influence of Programmed Physical Activity on Body Composition Among Adolescent Students [Efeito da Atividade Física Programada Sobre a Composiçã o Corporal Em Escolares Adolescentes]. J. Pediatr. 2009, 85, 28-34.

63. Farias, E.d.S.; de Carvalho, W.R.G.; Gonçalves, E.M.; Guerra-Júnior, G. Efeito Da Atividade Física Programada Sobre a Aptidão Física Em Escolares Adolescentes. Rev. Bras. Cineantropometria Desempenho Hum. 2010, 12, 98-105.

64. Farias, E.d.S.; Gonçalves, E.M.; Morcillo, A.M.; Guerra-Júnior, G.; Amancio, O.M.S. Effects of Programmed Physical Activity on Body Composition in Post-Pubertal Schoolchildren. J. Pediatr. 2015, 91, 122-129. [CrossRef] [PubMed]

65. Fiorante, F.B.; Pellegrinotti, Í.L. Efeitos de um programa periodizado de futsal na aptidão física de estudantes femininas de 13 e 14 anos de idade. RBFF Rev. Bras. Futsal Futeb. 2014, 10, 285-293.

66. Generosi, R.A. Efeitos de um Programa de Treinamento Físico em Componentes da Aptidão Física Relacionada à Saúde de Escolares. Master's Thesis, Universidade Federal do Rio Grande do Sul, Porto Alegre, Brazil, 2011.

67. Guimarães, R.d.F.; da Silva, M.P.; Martini, M.C.S.; Guerra-Júnior, G.; Gonçalves, E.M. The Effects of an After-School Intervention Program on Physical Activity Level, Sedentary Time, and Cardiovascular Risk Factors in Adolescents. Mot. Rev. Educ. Fís. 2017, 23. [CrossRef]

68. Maia, R.F. Efeitos da transferência de aprendizagem entre tarefas saque do voleibol para o saque do tênis. Rev. Mackenzie Educ. Fís. Esporte 2007, 6, 135-144.

69. Malfatti, C.R.M.; Burgos, M.S.; Juruena, G.S. Efeito do Jogging Aquático e Orientações Nutricionais No Percentual de Gordura e Capacidade Aeróbica Em Escolares. Fit. Perform. J. 2009, 8, 40-44.

70. Moreira, R.; Akagi, F.; Wun, P.; Moriguchi, C.; Sato, T. Effects of a School Based Exercise Program on Children's Resistance and Flexibility. Work 2012, 41, 922-928. [CrossRef]

71. Neto, C.F.; Neto, G.R.; Araújo, A.T.; Sousa, M.S.; Sousa, J.B.; Batista, G.R.; Reis, V.M. Can Programmed or Self-Selected Physical Activity Affect Physical Fitness of Adolescents? J. Hum. Kinet. 2014, 43, 125-130. [CrossRef]

72. Oliveira, L.; Braga, F.; Lemes, V.; Dias, A.; Brand, C.; Mello, J.; Gaya, A.; Gaya, A. Effect of an Intervention in Physical Education Classes on Health Related Levels of Physical Fitness in Youth. Rev. Bras. Ativ. Fís. Saúde 2017, 22, 46-53. [CrossRef]

73. Ribeiro, E.H.C. Efeito de dois programas de intervenção no nível de atividade física de adolescentes matriculados em escolas da rede pública de ensino da Zona Leste da cidade de São Paulo, SP. Master's Thesis, Universidade de São Paulo, São Paulo, Brazil, 2009.

74. Ribeiro, E.H.; Florindo, A.A. Efeitos de um Programa de Intervenção No Nível de Atividade Física de Adolescentes de Escolas Públicas de Uma Região de Baixo Nível Socioeconômico: Descrição dos Métodos Utilizados. Rev. Bras. Ativ. Fís. Saúde 2010, $15,28-34$.

75. Ritter, A.L.; de Souza, J.L. Postural Education Program for Elementary School: A One-Year Follow-up Study. Mot. Rev. Educ. Fis. 2015, 21, 256-262. [CrossRef]

76. Da Silva, A.Z.; Pereira, F.L.H.; Mincewicz, G.; de Araujo, L.B.; Guimarães, A.T.B.; Israel, V.L. Intervenção Psicomotora Para Estímulo Do Desenvolvimento Motor de Escolares de 8 a 10 Anos. Rev. Bras. Cineantropometria Desempenho Hum. 2017, 19, 150. [CrossRef]

77. Andrade, A.; da Cruz, W.M.; Correia, C.K.; Santos, A.L.G.; Bevilacqua, G.G. Effect of Practice Exergames on the Mood States and Self-Esteem of Elementary School Boys and Girls during Physical Education Classes: A Cluster-Randomized Controlled Natural Experiment. PLoS ONE 2020, 15, e0232392. [CrossRef]

78. Bandeira, A.d.S.; Beets, M.W.; da Silveira, P.M.; Lopes, M.V.V.; Filho, V.C.B.; da Costa, B.G.G.; Silva, K.S. Efforts on Changing Lifestyle Behaviors May Not Be Enough to Improve Health-Related Quality of Life Among Adolescents: A Cluster-Randomized Controlled Trial. Front. Psychol. 2021, 12, 614628. [CrossRef] [PubMed]

79. Bandeira, A.d.S.; Silva, K.S.; Bastos, J.L.D.; Silva, D.A.S.; Lopes, A.d.S.; Filho, V.C.B. Psychosocial Mediators of Screen Time Reduction after an Intervention for Students from Schools in Vulnerable Areas: A Cluster-Randomized Controlled Trial. J. Sci. Med. Sport 2020, 23, 264-269. [CrossRef] [PubMed]

80. Medeiros, P.; Felden, É.P.G.; Zequinão, M.A.; Cordeiro, P.C.; Dias de Freitas, K.T.; dos Santos, J.O.L.; Cardoso, F.L. Positive Effect of a Motor Intervention Program with Exergames: A Blind Randomized Trial. Int. J. Game Based Learn. 2020, 10, 55-64. [CrossRef]

81. Cairney, J.; Kiez, T.; Roetert, E.P.; Kriellaars, D. A 20th-Century Narrative on the Origins of the Physical Literacy Construct. J. Teach. Phys. Educ. 2019, 38, 79-83. [CrossRef]

82. Kipper, D.J. Ética Em Pesquisa Com Crianças e Adolescentes: À Procura de Normas e Diretrizes Virtuosas. Rev. Bioét. 2016, 24. [CrossRef]

83. Punch, S. Research with Children: The Same or Different from Research with Adults? Childhood 2002, 9, 321-341. [CrossRef]

84. Giblin, S.; Collins, D.; Button, C. Physical Literacy: Importance, Assessment and Future Directions. Sports Med. 2014, 44, 1177-1184. [CrossRef] 
85. Edwards, L.C.; Bryant, A.S.; Keegan, R.J.; Morgan, K.; Cooper, S.-M.; Jones, A.M. 'Measuring' Physical Literacy and Related Constructs: A Systematic Review of Empirical Findings. Sports Med. 2018, 48, 659-682. [CrossRef] [PubMed]

86. García-Hermoso, A.; Alonso-Martínez, A.M.; Ramírez-Vélez, R.; Pérez-Sousa, M.Á.; Ramírez-Campillo, R.; Izquierdo, M. Association of Physical Education with Improvement of Health-Related Physical Fitness Outcomes and Fundamental Motor Skills Among Youths: A Systematic Review and Meta-Analysis. JAMA Pediatr. 2020, 174, e200223. [CrossRef] [PubMed]

87. Minatto, G.; Filho, V.C.B.; Berria, J.; Petroski, E.L. School-Based Interventions to Improve Cardiorespiratory Fitness in Adolescents: Systematic Review with Meta-Analysis. Sports Med. 2016, 46, 1273-1292. [CrossRef]

88. Langford, R.; Bonell, C.; Jones, H.; Pouliou, T.; Murphy, S.; Waters, E.; Komro, K.; Gibbs, L.; Magnus, D.; Campbell, R. The World Health Organization's Health Promoting Schools Framework: A Cochrane Systematic Review and Meta-Analysis. BMC Public Health 2015, 15, 130. [CrossRef] [PubMed]

89. Rhodes, R.E.; Quinlan, A.; Naylor, P.-J.; Warburton, D.E.; Blanchard, C.M. Predicting Personal Physical Activity of Parents during Participation in a Family Intervention Targeting Their Children. J. Behav. Med. 2020, 43, 209-224. [CrossRef]

90. Hutchens, A.; Lee, R.E. Parenting Practices and Children's Physical Activity: An Integrative Review. J. Sch. Nurs. 2018, 34, 68-85. [CrossRef] 